\title{
Quantification of DNA content in freshwater microalgae using flow cytometry: a modified protocol for selected green microalgae
}

\author{
Petra Mazalová, Petra Šarhanová, Vladan OndŘej \& Aloisie PoulíčKová
}

Department of Botany, Faculty of Science, Palacký University Olomouc, Šlechtiteli̊ 11, CZ-783 71 Olomouc, Czech Republic; e-mail: petra.mazalova@upol.cz

\begin{abstract}
The study of genome size variation in microalgae lags behind that of comparable research in higher plants and seaweeds. This situation is essentially caused by: (1) difficulties in obtaining sufficient biomass for experiments; (2) problems with protoplast isolation due to cell-wall heterogeneity and complexity; and (3) the absence of suitable standards for routine measurements. We propose a multi-step protocol that leads to the quantification of DNA content in desmids using flow cytometry. We present detailed culture conditions, the minimal biomass necessary for three repetitive measurements, a method to isolate protoplasts and selection of suitable standards. Our protocol, which is mainly based on studies with higher plants and commercially available enzyme mixtures, is useful in Streptophyta, especially members of the Zygnematophyceae, because of their close phylogenetic relationship to higher plants, in particular the similarity of their cell wall organization. Moreover, the suggested protocol also works for some Chlorophyta (Chloroidium ellipsoideum, Tetraselmis subcordiformis) and Heterokontophyta (Tribonema vulgare). We suggest and characterize a new standard for flow cytometry of microalgae (Micrasterias pinnatifida). Modification of the enzyme mixture is probably necessary for microalgae whose cell walls are surrounded by a mucilaginous envelope (Planktosphaeria), those that contain alganan (Chlorella), monads with a pellicle or chlamys (Euglena, Chlamydomonas). While we did not anticipate any success with diatoms (Pinnularia), because of their silica frustules, the enzyme mixture also failed for some other green microalgae (Xanthidium, Kentrosphaera, Stigeoclonium, Trentepohlia and Pseudendoclonium).
\end{abstract}

Keywords: DNA content, flow cytometry, desmids, microalgae, standards, Micrasterias pinnatifida

\section{Introduction}

Although data relating to genome size are extremely important in the assessment of phylogenetic relationships in plants, there remain enormous gaps in the current genome size database. DNA content have so far been determined for 7058 species, comprising 6287 angiosperms, 204 gymnosperms, 82 pteridophytes, 232 bryophytes and 253 algae (BenNETT \& Leitch 2010). Genome size estimates have been studied by KAPRAUN (2005, 2007), who reported values for almost 400 species of red, green and brown macroscopic algae. Unicellular freshwater microalgae have rarely been studied (KAPRAUN 2007), but genome size data can be used for testing the role of polyploidy in algal evolution and speciation (MANN \& PoulíčKovÁ 2010), particularly in microalgal groups with sexual reproduction (Zygnematophyceae, Bacillariophyceae). Our research interests include cryptic diversity and reproductive isolation in desmids and so we tried to apply existing genome size estimation methods to this group of microalgae in particular.

Several methods have been used to quantify nuclear DNA in algae, primarily Feulgen microdensitometry and similar microspectrophotometric methods (HARDIE et al. 2002; KAPRAUN 2007). Although flow cytometry (FC) is routinely used in higher plants, it has rarely been used for microalgae (LE GALL et al. 1993; Simon et al. 1994; Veldhuis et al. 1997). Moreover these studies estimated nuclear DNA content from whole cells, but recently it turned out that only estimates based on isolated nuclei are accurate enough for general comparisons (KAPRAUN 2007).

In contrast to higher plants and seaweeds, studies on microalgae require isolation of single cells and maintainence of unialgal cultures to obtain a reasonable amount of biomass for experiments. As a result, research on microalgae is time consuming. In addition, we have found that methods for nuclei separation used in higher 
plants (chopping tissue with a razor blade; GalbRAith et al. 1983), do not work in our model microalgae, the desmids. Consequently, we tried grinding the material in a mortar, but this did not yield any positive results. Techniques for cell wall removal using cell wall-degrading enzymes have previously been used in higher plants for intact plant cells and in the preparation of somatic hybrids after protoplast fusion (DoležEL et al. 2007). This technique has also been used for some seaweeds (Millner et al. 1979; ButLer et al. 1990). However, algae are a heterogeneous group and exhibit a variety and complexity of cell wall organization which contrasts with the relative homogeneity characteristic of higher plants. As in higher plants, the algal cell wall can sometimes be interpreted as a two phase system: a crystalline phase (the skeleton) embedded in a more amorphous phase (the matrix). However, the algal cell wall differs from land plants in the abundance of matrix compounds compared to the skeletal components (BUTLER et al. 1990). In higher plants the three primary components of the cell wall are cellulose, hemicellulose and pectins, and protoplasts can be isolated from virtually any plant species using a combination of cellulases, hemicellulases and pectinases (BUTLER et al. 1990). Because of the phylogenetic position of desmids close to higher plants (Streptophyta), we decided to start with commercial preparations of enzymes available for the routine isolation of higher plant protoplasts. Propidium iodide was used as a fluorescent dye which intercalates quantitatively to the double-stranded DNA, therefore absolute DNA amount can be quantified.

Commonly used higher plant standards (Doležel et al. 1992), Pisum sativum, Lycopersicon esculentum, Raphanus sativus and Zea mays have been tested and used for characterization of new desmid standard.

In this study we aimed to develop a protocol for the quantification of nuclear DNA by flow cytometry suitable primarily for desmids. As the method consists of several steps, we aimed to find 1) an easy and fast culturing method to obtain a minimal biomass necessary for the experiments, 2) an easy way to isolate protoplasts and 3 ) a suitable standard for measurement of DNA content and/or define a new microalgal standard. We also tried to verify, by selective screening, whether our protocol is useful for other microalgae.

\section{Materials and methods}

Algal strains, media, culture conditions, cropping of cells and LM observations. The algal material used in these experiments was obtained from clonal unialgal cultures. Algal strains were either our isolates or those obtained from culture collections (Table 1). Our strains $(699,723,745$, Pin1Cra) were isolated using standard methods (ANDERSEN 2005) from Irish or Scottish lakes. They are held in the culture collection of the Department of Botany, Palacký University in Olomouc. Cultures were maintained at $16{ }^{\circ} \mathrm{C}$ with 12:12 light:dark cycle, under cool-white fluorescent lights at an irradiation of $20 \mu \mathrm{mol} . \mathrm{m}^{-2} \cdot \mathrm{s}^{-1}$.

Two basic liquid culture media were used: an oligotrophic medium for desmids used in the CAUP collection (OGM; Černá \& Neustupa 2010) and Bold's Basal medium for other microalgae (BBM; Bold 1949). Euglena was cultured in soil extract medium (ANDERSEN 2005) diluted 1:1 with distilled water, Tetraselmis in ASW medium (MCLACHLAN 1964) and Pinnularia in diatom medium WC with silicate (Guillard \& Lorenzen 1972). Storage cultures were kept in $50 \mathrm{~mm}$ Petri dishes. Subsequently, 2 weeks before planned flow cytometric measurements, a rich inoculum of each strain (ca $1 \mathrm{ml}$ ) was transfered to fresh medium in $100 \mathrm{~mm}$ Petri dishes and kept at a higher irradiation $\left(40 \mu \mathrm{mol} . \mathrm{m}^{-2} \cdot \mathrm{s}^{-1}\right)$ with 16:8 light:dark cycle. Approximately 10 days after subculturing, the bottom of the Petri dish was conspicuously green and such an amount of cells in exponential growth phase was used for cytometric measurements. For three replacated DNA measurements of each algal strain, we used three Petri dishes of material. Desmids were usually growing on the bottom of the Petri dish. Therefore superfluous medium was gently poured off and cells were carefully scraped from the bottom using a bacteriological squeegee and transfered into $15 \mathrm{ml}$ centrifuge tubes and centrifuged (1500 rpm for $5 \mathrm{~min}$ ). Superfluous medium was again gently removed and the sedimented cells were used for subsequent treatment. LM observations were done under a light Zeiss AxioImager microscope and Zeiss Axiovert inverted microscope.

Enzyme treatment. Conspicuously green cultures in the exponential phase of growth (10-15 days after inoculation) were concentrated by centrifugation so that the tip of a conical $15 \mathrm{ml}$ tube was filled with biomass. Then, $2 \mathrm{ml}$ of the enzymatic mixture of $2 \%$ Cellulase Onozuka R-10 (Duchefa Biochemie, Netherlands), 0.5\% Macerozyme R-10 (Duchefa Biochemie, Netherlands) dissolved in modified rinsing solution PGly (Table 2) was added (Debeaujon \& BRAnChard 1992). Suspensions were kept for $16 \mathrm{~h}$ in the dark at $27^{\circ} \mathrm{C}$. After $16 \mathrm{~h}$, suspensions were centrifuged (700 $\mathrm{rpm}$ for $5 \mathrm{~min}$ ), the supernatant was poured off and replaced by $1 \mathrm{ml}$ of PGly to rinse the pellet. Suspensions were recentrifuged (700 rpm for $5 \mathrm{~min}$ ) and PGly was 

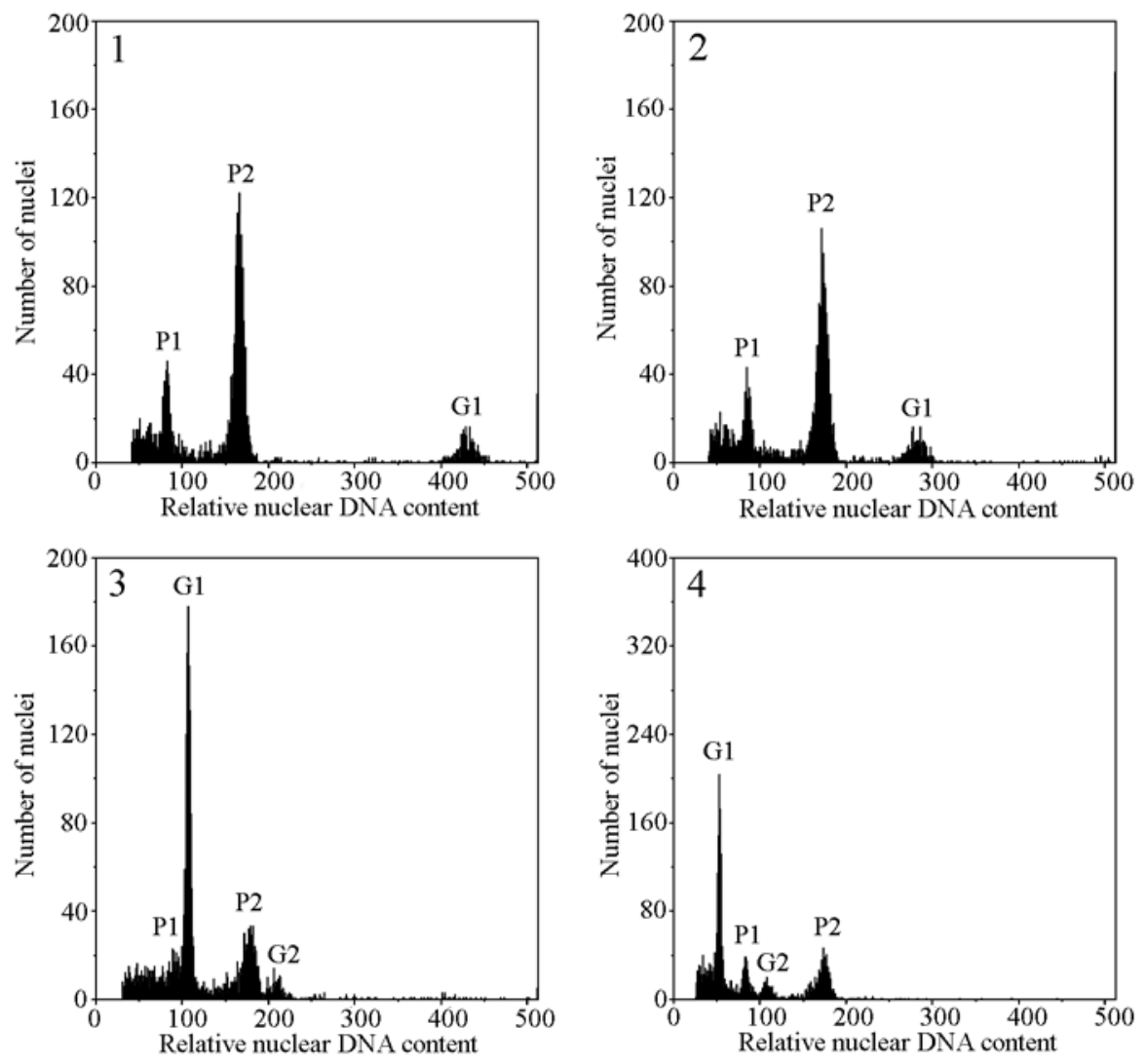

Fig. 1. Histograms of relative nuclear DNA content of Micrasterias pinnatifida (RALFS) and various standards: (1) Pisum sativum, (2) Zea mays, (3) Lycopersicon esculentum, (4) Raphanus sativus. (G1) G1 phase of the standards, (G2) G2 phase of the standards, (P1) haploid stage of the sample, (P2) diploid stage of the sample.

removed. The obtained biomass of cells was placed on ice before lysis buffer (flow cytometry) was added to protect the cells from regenerating cell walls and to enhance release of the nuclei from the treated cells.

Flow cytometry and DNA amount estimation. The absolute nuclear DNA amount of the studied algae was estimated by FC using a ML CyFlow instrument (Partec GmbH, Münster, Germany). Each sample was analyzed separately to choose a proper standard of different genome size, but still relatively close enough to the sample to avoid nonlinearity of the instrument. A second measurement of the studied samples was done together with the internal standard. Raphanus sativus cv. Saxa (2C = 1.11 pg, DoležEl et al. 1992), Lycopersicon esculentum cv. Stupicke $(2 \mathrm{C}=1.96 \mathrm{pg}$, DolEžEl et al. 1992), Zea mays, CE-777, (2C $=5.46 \mathrm{pg}$, SudA personal communication) or Pisum sativum cv. Ctirad ( $2 \mathrm{C}=8.76 \mathrm{pg}$, SudA personal communication) were used as standards. Leaf tissues of standards were chopped with a razor blade in $1 \mathrm{ml}$ of LB01 lysis buffer (15 mM TRIS; 2 mM EDTA; $0.5 \mathrm{mM}$ spermine-4HCl; $80 \mathrm{mM} \mathrm{KCl} ; 20 \mathrm{mM} \mathrm{NaCl} ; 0.1 \%$ Triton X-100; 15mM 2-mercaptoethanol.; pH 8.0; DoležEL et al. 1989). Then the algal solution was added to the chopped standard, mixed and the suspension of nuclei was filtered through nylon mesh $(42 \mu \mathrm{m})$ into a tube containing another $300 \mu \mathrm{l}$ of lysis buffer. After 1 hour incubation on ice, the suspension was decanted to a new tube to remove the sediment and $50 \mu$ of propidium iodid (PI) was added. Measurements were done on the flow cytometer up to 3000 particles. The absolute nuclear DNA amount was calculated from a linear ratio between G1 peak position of the standard and the peak of the sample according to DoLEžEL \& BARTOŠ (2005): (sample G1 peak mean / standard G1 peak mean) * standard 2C DNA content.

All samples were measured at least twice, usually three times. Some authors had shown that greater ploidy levels in one algal culture can occur (Hamada 1987; Haig 2010). Although we did not study the number of chromosomes or ploidy level, in those cases where we obtained two peaks, we labelled the first lower ploidy peak as $1 \mathrm{C}$ and the second main peak as $2 \mathrm{C}$ in accordance with GreILHUBER et al. (2005).

New microalgal standard identification. The vigorously growing desmid strain available in the Hamburg culture collection (Sammlung von ConjugatenKulturen), Micrasterias pinnatifida (KüTZING) ex RALFS (SVCK 411; http://www.biologie.uni-hamburg. de/b-online/d44_1/44_1.htm) has been characterized as a first microalgal standard.

Micasterias pinnatifida strain was measured seventeen times with different standards following the method described above. As internal standards, Pisum sativum was measured ten times, Zea mays four times, Lycopersycon esculentum twice and Raphanus sativus once. To cross-check genome sizes, standards were also analysed in combination: a) P. sativum, Z. mays and $R$. sativus and b) P. sativum and L. esculentum. 
Table 1. Basic characteristics of the strains under study. Sources of the strains: (ASW) Algensammlung Wien, University of Viena, nowadays deposit in the Culture Collection of Algae at the University of Cologne (CCAC); (CAUP) Culture Collection of Algae, Charles University in Prague, Czech Republic; (M) Research Culture Collection Melkonian, University of Cologne, Germany; (NIES) Microbial Culture Collection, National Institute for Environmental Studies, Japan; (SAG) Sammlung von Algenkulturen Göttingen, University of Göttingen, Germany; (SVCK) Sammlung von Conjugaten-Kulturen (http://www.biologie.uni-hamburg.de/b-online/d44_1/44_1.htm). The strains not held by above mentioned collections are keeping in culture collection of the Department of Botany, Palacký University in Olomouc (Czech Republic).

\begin{tabular}{|c|c|c|c|c|}
\hline & Species & Strain & Origin/locality & Medium \\
\hline \multirow[t]{14}{*}{ Zygnematophyceae } & $\begin{array}{l}\text { Cosmarium contractum KIRCH- } \\
\text { NER }\end{array}$ & M 3039 & Doksy (CZ) & OGM \\
\hline & Euastrum verrucosum RALFS & 699 & $\begin{array}{l}\text { Lough an Fhraoigh } \\
\text { (Connemara, IRL) }\end{array}$ & OGM \\
\hline & Micrasterias pinnatifida RALFS & SVCK 411 & $\begin{array}{l}\text { Laguna de Mucubaji, } \\
\text { Merida (YV) }\end{array}$ & OGM \\
\hline & Micrasterias rotata RALFS & SVCK 212 & near Potsdam (D) & OGM \\
\hline & $\begin{array}{l}\text { Micrasterias truncata var. } \\
\text { pusilla G.S. WEST }\end{array}$ & NIES 783 & $\begin{array}{l}\text { Centenial Park (Sydney, } \\
\text { AUS) }\end{array}$ & OGM \\
\hline & $\begin{array}{l}\text { Pleurotaenium ehrenbergii } \\
\text { (RALFS) DE BARY }\end{array}$ & 745 & $\begin{array}{l}\text { vicinity of Upper Lake } \\
\text { (Kerry, IRL) }\end{array}$ & OGM \\
\hline & $\begin{array}{l}\text { Staurastrum arctiscon (RALFS) } \\
\text { LuNDELL }\end{array}$ & 723 & $\begin{array}{l}\text { Lough Eirk (Kerry, } \\
\text { IRL) }\end{array}$ & OGM \\
\hline & Staurastrum orbiculare RALFS & M 2217 & $\begin{array}{l}\text { vicinity of Vladivostok } \\
\text { (RU) }\end{array}$ & OGM \\
\hline & $\begin{array}{l}\text { Staurodesmus dickiei (RALFS) } \\
\text { LiLLIEROTH }\end{array}$ & ASW 07056 & $\begin{array}{l}\text { fen Rotmoos near Horn- } \\
\text { spitz (AUS) }\end{array}$ & OGM \\
\hline & Triploceras gracile BAILEY & SAG 24.82 & $\begin{array}{l}\text { Rotary Pond at Falmou- } \\
\text { th (MA, USA) }\end{array}$ & OGM \\
\hline & Triploceras gracile BAILEY & SVCK 366 & Sumatra & OGM \\
\hline & Xanthidium octocorne RALFS & M3057 & Pískovny Cep (CZ) & OGM \\
\hline & $\begin{array}{l}\text { Zygnema circumcarinatum } \\
\text { CzURDA }\end{array}$ & $\begin{array}{l}\text { CAUP K } \\
402 \mathrm{a}\end{array}$ & $\begin{array}{l}\text { meadow ditch near } \\
\text { Doksy }(\mathrm{CZ})\end{array}$ & $\mathrm{BBM}$ \\
\hline & $\begin{array}{l}\text { Zygnema cylindricum TRAN- } \\
\text { SEAU }\end{array}$ & CAUP K 403 & Doksy (CZ) & $\mathrm{BBM}$ \\
\hline Klebsormidiophyceae & $\begin{array}{l}\text { Klebsormidium flaccidum } \\
\text { (KüTZING) SiLVA, MATtox \& } \\
\text { BLACKWELL }\end{array}$ & CAUP J 302 & Adršpach (CZ) & $\mathrm{BBM}$ \\
\hline \multirow[t]{2}{*}{ Trebouxiophyceae } & $\begin{array}{l}\text { Chloroidium ellipsoideum } \\
\text { (GERNECK) DARIENKO et al. }\end{array}$ & $\begin{array}{l}\text { CAUP H } \\
1949\end{array}$ & $\begin{array}{l}\text { on a tree bark, Adršpach } \\
(\mathrm{CZ})\end{array}$ & $\mathrm{BBM}$ \\
\hline & Chlorella vulgaris BEYERINCK & $\begin{array}{l}\text { CAUP H } \\
1993\end{array}$ & $\begin{array}{l}\text { Žebrákovský creek, } \\
\text { Czech-Moravian High- } \\
\text { lands }(\mathrm{CZ})\end{array}$ & $\mathrm{BBM}$ \\
\hline \multirow[t]{4}{*}{ Chlorophyceae } & Stigeoclonium sp. & CAUP J 603 & $\begin{array}{l}\text { Žebrákovský creek, } \\
\text { river basin of Sázava, } \\
\text { Czech-Moravian High- } \\
\text { lands (CZ) }\end{array}$ & $\mathrm{BBM}$ \\
\hline & Chlamydomonas geitleri ETTL & CAUP G 224 & pond near Opatov (CZ) & BBM \\
\hline & $\begin{array}{l}\text { Desmodesmus communis (E. } \\
\text { HeGEWALD) E. HEGEWALD }\end{array}$ & CAUP H 522 & unknown & $\mathrm{BBM}$ \\
\hline & $\begin{array}{l}\text { Planktosphaeria gelatinosa } \\
\text { G.M.SмIтн }\end{array}$ & $\begin{array}{l}\text { CAUP H } \\
1401\end{array}$ & $\begin{array}{l}\text { soil from garden, Wo- } \\
\text { ods Hole (MA, USA) }\end{array}$ & $\mathrm{BBM}$ \\
\hline
\end{tabular}


Table 1 Cont.

\begin{tabular}{|c|c|c|c|c|}
\hline \multirow[t]{3}{*}{ Ulvophyceae } & Kentrosphaera sp. & $\begin{array}{l}\text { CAUP H } \\
5308\end{array}$ & $\begin{array}{l}\text { soil, top of the Boreč } \\
\text { Hill (České Středohoří } \\
\text { Mts, CZ) }\end{array}$ & BBM \\
\hline & $\begin{array}{l}\text { Pseudendoclonium basiliense } \\
\text { VISCHER }\end{array}$ & SAG $466-2$ & $\begin{array}{l}\text { bog water, Bot. Gard. } \\
\text { Univ. Basel }(\mathrm{CH})\end{array}$ & BBM \\
\hline & Trentepohlia sp. & CAUP J 1601 & bark, Singapore & BBM \\
\hline Prasinophyceae & $\begin{array}{l}\text { Tetraselmis subcordiformis } \\
\text { (WILLE) BUTCHER }\end{array}$ & CAUP M 201 & Sandy Hook (NJ, USA) & ASW \\
\hline Bacillariophyceae & $\begin{array}{l}\text { Pinnularia } \text { cf. gibba EHREN- } \\
\text { BERG }\end{array}$ & Pin1Cra & Loch of Craiglush (UK) & WC \\
\hline Euglenophyceae & Euglena gracilis KLEBS & CAUP E 201 & $\begin{array}{l}\text { peaty pool nearby Třti- } \\
\text { ce (CZ) }\end{array}$ & $\begin{array}{l}\text { soil } \\
\text { extract } \\
\text { medium }\end{array}$ \\
\hline Xanthophyceae & Tribonema vulgare PASCHER & CAUP D 501 & $\begin{array}{l}\text { Palach Pond near Led- } \\
\text { nice }(C Z)\end{array}$ & $\mathrm{BBM}$ \\
\hline
\end{tabular}

\section{Results and discussion}

\section{Range of tested microalgae}

This paper proposes an easy protocol for the quantification of nuclear DNA by flow cytometry, suitable primarily for Zygnematophyceae, but also useful for some other microalgae, depending in particular on cell wall organization. We tested 28 microalgal cultures and succeeded with Streptophyta representatives (Desmidiales, Zygnematales and Klebsormidiales; Table 3). In addition, 39 desmid cultures of the genus Micrasterias sensu lato have been successfully analyzed in another study (ŠKALOUD unpublished). Although the protocol (particularly protoplast isolation) failed in Bacillariophyceae, Euglenophyta and most of the tested Chlorophyta, it was successful for Chloroidium ellipsoideum (Oocystaceae), Tetraselmis subcordiformis (Prasinophyceae) and Tribonema vulgare (Xanthophyceae, Heterokontophyta).

\section{Minimum biomass requirement and culture conditions}

In contrast to higher plants and seaweeds, biomass for microalgal experiments originates from clonal unialgal cultures. From our experience, most of the tested species grow well in liquid media. We mostly used culture media for green microalgae and desmids (Bold's Basal medium-BBM; BoLD 1949 and oligotrophic medium for desmids as used in the CAUP collection-OGM; ČERNÁ \& NEUSTUPA 2010) and an elevated irradiance level compared to maintenance cultures $\left(40 \mu \mathrm{mol} \cdot \mathrm{m}^{-2} \cdot \mathrm{s}^{-1}\right)$. Under such conditions we obtained from each Petri dish sufficient cell suspension for at least one measurement. In the case of Micrasterias rotata, a greater degree of biomass cover of the Petri dish was necessary to yield a sufficient amount of cell suspension. In contrast, the suspensions of small genome size species including Tetraselmis subcordiformis and Tribonema vulgare were highly concentrated and one microliter of the suspension was sufficient for the flow cytometric analysis. The species with larger genome sizes tend to have bigger cells (GREGORY 2001; LEITCH $\&$ BenNetT 2007) and therefore the cover of the Petri dish seems to be more intense. Consequently the real amount of cells rather than the intensity of green colour is crucial for sufficient concentration of cells in the FC-solution. Culturing in Petri dishes is cheap, does not require a lot of space and the health and density of the culture can easily be checked under an inverted microscope (PoulíčKová \& ManN 2006).

\section{Protoplast isolation}

Isolated protoplasts are living plant cells from which the walls have been removed. They provide a large, relatively homogeneous suspension of wall-less, single plant cells for physiological and biochemical research. Protoplasts surrounded only by a plasma membrane are a convenient starting material for obtaining high yields of delicate cell organelles such as nuclei or microbodies. Techniques for the removal of the cell wall using cell wall-degrading enzymes were developed in the 1960s and are routinely used in 
Table 2. Composition of the modified solution PGly (original: Debeaujon \& Branchard 1992). With continuous stirring dissolve all components in distilled water. Bring the total volume to $1000 \mathrm{ml}$. Adjust to $\mathrm{pH} 5.8$ with $1 \mathrm{M} \mathrm{HCl}$ and sterilize by filtration. *MES $2-(N$-morpholino)ethanesulfonic acid

\begin{tabular}{lll}
\hline & Component & g. $1^{-1} \mathrm{H}_{2} \mathrm{O}$ \\
\hline PGly & $\mathrm{KH}_{2} \mathrm{PO}_{4}$ & 0.0272 \\
& $\mathrm{KNO}_{3}$ & 0.101 \\
$\mathrm{CaCl}_{2}$ (anhydrous) & 1.1176 \\
$\mathrm{MgSO}_{4} .7 \mathrm{H}_{2} \mathrm{O}$ & 0.246 \\
glycine & 11.15 \\
glucose & 18.016 \\
MES* & 0.5857 \\
manitol & 65.58 \\
\hline
\end{tabular}

higher plants (TAKeBe \& OTSUKi 1969; Cocking 1960; DoležEL et al. 2007) for biotechnological purposes. In principle, there is no reason why such techniques cannot be successfully applied to algae. Methods for preparation of protoplasts of marine macroalgae have been developed only recently (ButLer et al. 1990; INOUE et al. 2010; WAKABAYASHI et al. 1999) and have never been used for microalgae. The algal cell wall differs from land plants in its heterogeneity and complexity. Commercial mixtures of enzymes routinely used in higher plants mostly consist of cellulases, hemicellulases and pectinases. Cellulose is very abundant in green algae, in which it accounts for up to $70 \%$ of the cell wall (PRESTON 1974). On the other hand, the cellulose content of most brown and red algae is low, being less than $10 \%$ and some algae do not contain any cellulose (BUTLER et al. 1990). Our recent research focuses primarily on desmids, which belong to Streptophyta, thus a high similarity of their cell wall organization with higher plants can be expected. There exist actually differences in cell wall composition within different algal taxa (STACE 1991), but the concentrations of the main cell wall polymers of land plants are similar to that of Streptophyta (Eder et al. 2008, ANDERson \& King 1961).

We modified the enzyme mixture used for the genera Cucumis and Cucurbita (GAJDOvÁ et al. 2007; ONDŘEJ et al. 2009) and marine green macroalgae (ReDDY et al. 2006; UpPalapati \& FustTA 2002; Chen \& SHIH 2000). After this treatment we were able to measure the amount of DNA in desmids (Cosmarium contractum, Euastrum verrucosum, Micrasterias pinnatifida,
Micrasterias rotata, Micrasterias truncata Pleurotaenium ehrenbergii, Staurastrum arctiscon, Staurastrum orbiculare, Staurodesmus dickiei,Triploceras gracile), someothermicroalgae within Streptophyta (Klebsormidium flaccidum, Zygnema circumcarinatum and Zygnema cylindricum), a few Chlorophyta (Chloroidium ellipsoideum, Tetraselmis subcordiformis) and Heterocontophyta (Tribonema vulgare). However, in contrast to higher plant samples, the algal cell walls have not been digested completely by the enzymes in some cases. Sometimes the desmid cell wall was eliminated only from one (younger) semicell, or protoplast left the cell wall by the split in the isthmus area. However, even these samples were often useful for flow cytometric measurements. This is the reason why young cultures (in the exponential growth phase) are recommended, because the cell wall is not fully developed. The method failed in the cases of Chlorella vulgaris and Desmodesmus communis. Their cell walls contain alganan and Planktosphaeria gelatinosa has a robust mucilaginous envelope. As we expected, we did not successed in the diatom Pinnularia cf. gibba on account of its silica frustule, nor monads with protein-containing periplast [Euglena gracilis, Chlamydomonas geitleri] (Graham et al. 2008). The enzyme mixture also failed for Xanthidium octocorne, Kentrosphaera sp., Stigeoclonium sp., Trentepohlia sp. and Pseudendoclonium basiliense. Specific enzyme mixtures will be necessary for these microalgae.

\section{Flow cytometry and DNA amount estimation}

$\mathrm{FC}$ is the optimal method for nuclear genome size estimation. Compared to traditional methods like Feulgen microdensitometry, scanning microspectrophotometry or DNA image cytometry which were used in the past, the FC enables the measurement of large amounts of cells in a short period of time (DOLEŽEL \& BARTOš 2005). Usability of FC for estimation of DNA amount from whole cells or protoplasts refers to cytoplasmatic autofluorescens and nonspecific background which lead to overestimation of results (KAPRAUN 2007; Veldhuis et al. 1997). Therefore release of the nuclei from the protoplast by lysis buffer enables precise estimation of the nuclear genome size. One of the most important steps in genome size estimation is the selection of an appropriate standard. It should have a genome size close to the peaks of the target material, but not overlap with 
Table 3. Absolute nuclear DNA amount in species. *Raphamus sativus cv, saxa (2C $=1.11 \mathrm{pg}$, DoLEŽEL et al. 1992), Lycopersicon esculentum cv. stupicke ( $2 \mathrm{C}=1.96 \mathrm{pg}$, DolEŽEL et al. 1992), Zea mays CE-777 (2C = $5.46 \mathrm{pg}$, Suda personal communication) or Pisum sativum $\mathrm{cv}$. ctirad ( $2 \mathrm{C}=8.76$, Suda personal communication); $(\mathrm{x})$ measurement failed, (AVG) average, (STD) standard deviation.

\begin{tabular}{|c|c|c|c|c|}
\hline & Species & Strain & $\begin{array}{l}\text { DNA amount (pg) } \\
\text { AVG } \pm \text { STD }\end{array}$ & Standard species* \\
\hline \multirow[t]{14}{*}{ Zygnematophyceae } & Cosmarium contractum KIRCHNER & M 3039 & $5.72 \pm 0.11$ & Pisum a Zea \\
\hline & Euastrum verrucosum RALFS & 699 & $14.84 \pm 0.12$ & Pisum \\
\hline & M. pinnatifida RALFS & SVCK 411 & $3.40 \pm 0.07$ & $\begin{array}{l}\text { Lycopersicon, Pisum, } \\
\text { Raphanus, Zea }\end{array}$ \\
\hline & M. rotata RALFS & SVCK 212 & $26.35 \pm 0.12$ & Zea \\
\hline & M. truncata var. pusilla G.S. WEST & NIES-783 & $5.75 \pm 0.10$ & Pisum \\
\hline & $\begin{array}{l}\text { Pleurotaenium ehrenbergii } \\
\text { (RALFS) DE BARY }\end{array}$ & 745 & $8.97 \pm 0.17$ & Zea \\
\hline & $\begin{array}{l}\text { Staurastrum arctiscon (RALFS) } \\
\text { LUNDELL }\end{array}$ & 723 & $7.20 \pm 0.01$ & Zea \\
\hline & Staurastrum orbiculare RALFS & M 2217 & $2.81 \pm 0.01$ & Pisum \\
\hline & $\begin{array}{l}\text { Staurodesmus dickiei (RALFS) } \\
\text { LILLIEROTH }\end{array}$ & ASW 07056 & $2.05 \pm 0.00$ & Zea \\
\hline & Triploceras gracile BAILEY & SAG 24.82 & $9.39 \pm 0.07$ & Zea \\
\hline & Triploceras gracile BAILEY & SVCK 366 & $28.20 \pm 0.14$ & Pisum \\
\hline & Xanthidium octocorne RALFS & M 3057 & $\mathrm{x}$ & $\mathrm{x}$ \\
\hline & $\begin{array}{l}\text { Zygnema circumcarinatum } \\
\text { CZURDA }\end{array}$ & $\begin{array}{l}\text { CAUP K } \\
402 \mathrm{a}\end{array}$ & $3.07 \pm 0.06$ & Zea \\
\hline & Zygnema cylindricum TRANSEAU & $\begin{array}{l}\text { CAUP K } \\
403\end{array}$ & $2.51 \pm 0.00$ & Zea \\
\hline Klebsormidiophyceae & $\begin{array}{l}\text { Klebsormidium flaccidum } \\
\text { (KüTZING) SILVA, MATTOX \& } \\
\text { BLACKWELL }\end{array}$ & CAUP J 302 & $0.28 \pm 0.01$ & Lycopersicon \\
\hline \multirow[t]{2}{*}{ Trebouxiophyceae } & $\begin{array}{l}\text { Chloroidium ellipsoideum } \\
\text { (GERNECK) DARIENKO et al. }\end{array}$ & $\begin{array}{l}\text { CAUP H } \\
1949\end{array}$ & $1.21 \pm 0.03$ & Zea \\
\hline & Chlorella vulgaris BEYERINCK & $\begin{array}{l}\text { CAUP H } \\
1993\end{array}$ & $\mathrm{x}$ & $\mathrm{x}$ \\
\hline \multirow[t]{4}{*}{ Chlorophyceae } & Stigeoclonium sp. & CAUP J 603 & $\mathrm{x}$ & $\mathbf{x}$ \\
\hline & Chlamydomonas geitleri ETTL & $\begin{array}{l}\text { CAUP G } \\
224\end{array}$ & $\mathrm{x}$ & $\mathbf{x}$ \\
\hline & $\begin{array}{l}\text { Desmodesmus communis (E. } \\
\text { HEGEWALD) E. HEGEWALD }\end{array}$ & $\begin{array}{l}\text { CAUP H } \\
522\end{array}$ & $\mathrm{x}$ & $\mathrm{x}$ \\
\hline & $\begin{array}{l}\text { Planktosphaeria gelatinosa } \\
\text { G.M.SMITH }\end{array}$ & $\begin{array}{l}\text { CAUP H } \\
1401\end{array}$ & $\mathrm{x}$ & $\mathrm{x}$ \\
\hline \multirow[t]{3}{*}{ Ulvophyceae } & Kentrosphaera sp. & $\begin{array}{l}\text { CAUP H } \\
5308\end{array}$ & $\mathrm{x}$ & $\mathrm{x}$ \\
\hline & $\begin{array}{l}\text { Pseudendoclonium basiliense } \\
\text { VISCHER }\end{array}$ & SAG 466-2 & $\mathrm{x}$ & $\mathrm{x}$ \\
\hline & Trentepohlia sp. & $\begin{array}{l}\text { CAUP J } \\
1601\end{array}$ & $\mathrm{x}$ & $\mathbf{x}$ \\
\hline Prasinophyceae & $\begin{array}{l}\text { Tetraselmis subcordiformis } \\
\text { (WILLE) BUTCHER }\end{array}$ & $\begin{array}{l}\text { CAUP M } \\
\quad 201\end{array}$ & $1.20 \pm 0.03$ & Lycopersicon, Zea \\
\hline Bacillariophyceae & Pinnularia cf. gibba EHRENBERG & Pin1Cra & $\mathrm{x}$ & $\mathbf{x}$ \\
\hline Euglenophyceae & Euglena gracilis KLEBS & $\begin{array}{l}\text { CAUP E } \\
201\end{array}$ & $\mathrm{x}$ & $x$ \\
\hline Xanthophyceae & Tribonema vulgare PASCHER & $\begin{array}{c}\text { CAUP D } \\
501\end{array}$ & $0.41 \pm 0.00$ & Raphanus \\
\hline
\end{tabular}

the cells of interest (Price \& JOHNSTON 1996). If the genome sizes are too dissimilar, non-linearity of the instrument can arise. We chose different plant standards for different samples to avoid overlapping or nonlinearity of the instrument (Table 3). In three cases (Micrasterias pinnatifida, Cosmarium contractum and Tetraselmis subcordiformis) more standards were used to choose the optimal one. Results did not lead to significant differences in estimated genome size.

At present two standard fluorescent dyes are routinely used for DNA staining for FC measurements: 4',6-diamidino-2-phenylindole (DAPI) binding to AT-rich regions (BARCELLONA et al. 1986) and propidium iodide (PI) intercalating to the whole DNA (Crissman \& STEINKAMP 1973). The applicability of DAPI staining in absolute DNA amount measurements clashes 
with unbalanced proportion of different bases in the genome. BAROW \& MeIster (2002) have shown that the proportion of AT:GC-rich regions in higher plants is not equal between families nor species. The intraspecific differences were also documented by ŠMARDA et al. (2008) on fescues which range from $42.53 \%$ to $46.41 \%$. Similar variation with a range from $42.9 \%$ to $46.7 \%$ was detected for several algae species by LE GALL et al. (1993). The most marked discrepancy caused by the use of specifically binding dyes was shown by DoležEl et al. (1992). They found that the difference was caused not only by the differences in overall $\mathrm{AT} / \mathrm{GC}$ ratios for studied material and standard, but also by the species-specific differences in binding of these fluorochromes to DNA. Hence, use of PI for absolute genome size estimation is unambiguous.

Our protocol succeeded in 17 cases from 28 cultures used in this study. The estimated absolute nuclear DNA amount in these 17 microalgal cultures varied from $0.28 \mathrm{pg}$ to $28.2 \mathrm{pg}$ (Table 3 ). The two smallest genomes belong to the families Klebsormidophyceae (Klebsormidium flaccidum - $0.28 \mathrm{pg}$ ) and Xanthophyceae (Tribonema vulgare $-0.41 \mathrm{pg}$ ). Variability in the family Zygnematophyceae ranged from 2.05 to $28.2 \mathrm{pg}$, which probably reflects an increase in ploidy level during diversification and evolution of the species. This phenomenon was previously described by WANG et al. (1986) for polyploid series of Spirogyra maxima (Zygnemataceae) in both culture and wild populations. The original culture developed into three ploidy levels: $2 \mathrm{x}, 3 \mathrm{x}$ and $4 \mathrm{x}$ in accordance to findings in natural populations. In contrast, Hoshaw et al. (1985) observed a spontaneous decrease in ploidy level in clonal cultures of Spyrogira singularis. KAPRAUN (2007) recorded a range of 2C nuclear DNA content for Chlorophyta from 0.01 to $5.8 \mathrm{pg}$ and for Streptophyta from 0.2 to $6.4 \mathrm{pg}$ excluding the highly polyploid Desmidiales which have geonome sizes of up to $46.8 \mathrm{pg}$. Our results are broadly comparable with recorded ranges, however as we did not determine ploidy level of the studied cultures, we used terminology of $2 \mathrm{C}$ value only in cases with two peaks (desmids, Zygnematophyceae). In the case of primitive unicellular algae (Chloroidium ellipsoideum) the DNA amount (Table 3) should represent the haploid vegetative stage, while the situation in algae with sexual reproduction (desmids, diatoms) can be more complicated.

We detected in 5 of 17 algal cultures (Cosmarium contractum, Micrasterias pinnatifida, M. truncata var. pusilla, Staurastrum arctiscon and Zygnema circumcarinatum) two peaks = ploidy levels where the first peak (most likely 1C level) was notably smaller than the second (2C). This phenomenon was reviewed for several algae species by HAIG (2010). They explain that occurence of both haploid and diploid cells is caused by the meiosis and syngamy both followed by mitosis leading to vegetative growth of the two ploidy levels in culture.

Interesting differences were found in the case of two strains of Triploceras gracile. The strain isolated from Sumatra with $28.2 \mathrm{pg}$ has a DNA content three times higher than the strain isolated from USA ( $9.39 \mathrm{pg})$. The same phenomenon was detected by KASPRIK (1973), who counted numbers of chromosomes of several Micrasterias species. He detected different numbers of chromosomes in each population of $M$. americana corresponding to three ploidy levels: $2 \mathrm{x}, 3 \mathrm{x}$ and $4 \mathrm{x}$.

The coefficient of variation (CV) refers to the quality of the relative fluorescent peaks. In most cases CVs below 3\% are acceptable as CVs below 5\% are considered to be sufficient for "problematic" species (Doležel \& Bartoš 2005). DAPI staining shows lower CVs than those for PI as the binding of DNA is not influenced by chromatine structure (SANTISTEBAn et al. 1992). Coefficients of variation in our study varied from $2.35 \%$ (Micrasterias pinnatifida, selected as a

Table 4. Values of the absolute nuclear DNA amount (pg) of standards used in our study, from different sources.

\begin{tabular}{lccccc}
\hline & $\begin{array}{l}\text { DoležEL et al. } \\
(1992)\end{array}$ & $\begin{array}{l}\text { DoležEL et al. } \\
(1998)\end{array}$ & $\begin{array}{l}\text { LySÁK \& Dole- } \\
\text { ŽEL (1998) }\end{array}$ & $\begin{array}{l}\text { JoHnston et al. } \\
(1999)\end{array}$ & $\begin{array}{l}\text { SudA personal } \\
\text { communication }\end{array}$ \\
\hline Raphanus sativus & 1.11 & 1.41 & & & 1.12 \\
$\begin{array}{l}\text { Lycopersicon } \\
\text { esculentum }\end{array}$ & 1.96 & & & & 1.96 \\
Zea mays & 5.72 & 5.82 & 5.43 & 5.73 & 5.46 \\
Pisum sativum & 9.07 & 9.09 & & 9.39 & 8.76 \\
\hline
\end{tabular}


new standard for microalgae) to $5.38 \%$, with only one exception (Tetraselmis subcordiformis; 14.76 $\%$ ), which was excluded from the analysis. Gating of the peaks (understand as trimming of the peak with high background) was necessary in the case of Micrasterias rotata and Chloroidium ellipsoideum, to obtain explicit results. Modification of the protoplast isolation enzymatic mixture for these species could lead to better results.

In the case of the filamentous species Zygnema circumcarinatum and Z. cylindricum, chopping of the sample with a razor blade after enzyme treatment was necessary for nuclei isolation. We tested the hypothesis that chopping without enzymatic treatment is sufficient for cytometric analyses for $Z$. cylindricum as it is possible for most of the higher plants. Coefficient of variation in that case was $21.65 \%$ in comparison with the chopped sample treated with enzymes $\mathrm{CV}=5.15 \%$. Nevertheless, analysis of unchopped and enzymatically treated sample did not give any results.

\section{New microalgal standard M. pinnatifida}

As we have shown in our study, the genome size of microalgae may differ largely from one to another species or population. Selection of a suitable standard is necessary for precise analyses. In the last few decades, different standards for FC analyses were used e.g. human leucocytes (LYSÁK et al. 2000), chicken red blood cells (CRBCs, Galbraith et al. 1983; Veldhuis et al. 1997), salmon erythrocytes (IVERSEN \& LAERUM 1987) or different plant species (various authors). As was proven by many authors (Doležel et al. 1992; Johnston et al. 1999; Galbraith et al. 1983; TIERsCh et al. 1989), human and chicken cells do not seem to be a convenient standard for genome size estimation due to intraspecific and sexrelated variation (DE VITA et al. 1994; MeFFord et al. 1997). For absolute genome size estimation, use of biologically similar material with identical sample preparation is recommended (DoLEŽEL $\&$ BARTOŠ 2005). Therefore we suggest a new algal standard, Micrasterias pinnatifida for FC estimations, which can be the starting point for FC-standards development suitable for material of isolated protoplasts. The species match most of the requirements for such standards: unproblematic preparation leading to narrow peaks with low $\mathrm{CV}$, simultaneous preparation of standard and protoplast samples prior to cytometric analyses, available in sufficient quantities, easy to cultivate and distribute to other laboratories and stable genome size due to vegetative propagation. In addition it seems to be free of compounds interfering with PI staining.

In the majority of the 17 measurements of Micrasterias pinnatifida, two peaks of nuclear DNA were detected. In four measurements the first peak was not detected, although CV for the second peak was low, indicating that the absence was not caused by debris in the sample. To identify the genome size of $M$. pinnatifida, all four plant standards were used as the primary reference standards (Fig. 1). However, the use of Lycopersicon and Raphanus as internal standards refers to alternating of $1 \mathrm{C}$ and $2 \mathrm{C}$ peaks (Fig. 1) and increase the CV and inaccuracy of the measurement. Therefore we decided to exclude these standards from absolute genome size estimation. The genome size of new algal standard was counted from 14 analyses with Pisum and $\mathrm{Zea}$, whose means of CVs were $3.63 \%$ for alga, $2.36 \%$ for Pisum and $3.59 \%$ for Zea. In all cases peak of $2 \mathrm{C}-$ value of alga was narrow and with maximum $\mathrm{CV}=4.61 \%$. The determined size of Micrasterias pinnatifida from Hamburg culture collection is $3.4 \mathrm{pg} \pm 0.07$.

To validate the DNA amount of internal standards (Table 4) we measured them in combination: a) Pisum sativum, Zea mays and Raphanus sativus or b) Pisum sativum and Lycopersicon esculentum. Cross calculation gave means of genome sizes: $8.77 \mathrm{pg}$ for P. sativum, $5.48 \mathrm{pg}$ for $Z$. mays, $1.95 \mathrm{pg}$ for $L$. esculentum and $1.09 \mathrm{pg}$ for $R$. sativus. The standard deviation of known and counted genome sizes did not exceed 0.01 and we consider use of known genome sizes as legitimate.

\section{Acknowledgements}

The authors are grateful to Kath Evans (University of Edinburgh) for English corrections. The research was supported by projects GACR 206/09/0906, 206/08/0389 and IGA PrF_2011_003. We are grateful to P. Škaloud (Charles University of Prague) for inspirative comments and for providing us with cultures.

\section{References}

Andersen, R. A. (ed.) (2005): Algal culturing technique. - 596 pp., Academic Press, London.

Anderson, D.M.W. \& KInG, N. J. (1961): Polysaccharides of the Characeae III. The carbohydrate content of Chara australis. - Biochimica et Biophysica Acta 52: 449-454. 
Barcellona, M.L., Favilla, R., von Berger, J., Avitabile, M., Ragusa, N. \& Masotti, L. (1986): DNA-4'-6-diamidine-2-phenylindoilnete ractions: A comparative study employing fluorescence and ultraviolet spectroscopy. Arch Biochem Biophys 250: 48-53.

Barow, M. \& Meister, A. (2002): Lack of Correlation Between AT Frequency and Genome Size in Higher Plants and the Effect of Nonrandomness of Base Sequences on Dye Binding. - Cytometry 47: 1-7.

Bennett, M.D. \& Leitch, I.J. (2010): Plant DNA C-values database. http://data.kew.org/cvalues/ updates.html

Bold, H.C.(1949): The morphology of Chlamydomonas chlamydogama sp. nov. - Bulletin of the Torrey Botanical Club 76: 101-108.

Butler, D.M., Evans, L.V. \& Kloareg, B. (1990): Isolation of protoplasts from marine macroalgae. - In: Akatsuka, I. (ed.): Introduction to Applied Phycology. - pp. 647-668, SPB Academic Publication, The Hague, The Netherlands.

Černá, K. \& Neustupa, J. (2010): The pH-related morphological variations of two acidophilic species of Desmidiales (Viridiplantae) isolated from a lowland peat bog, Czech Republic. Aquatic Ecology 44: 409-419.

Chen, Y.-C. \& Shin, H.-C. (2000): Development of protoplasts of Ulva fasciata (Chlorophyta) for algal seed stock. - Journal of Phycology 36: 608-615.

Cocking, E.C. (1960): A method for the isolation of plant protoplasts and vacuoles. - Nature 187: 927-929.

Crissman, H.A. \& Steinkamp, J.A. (1973): Rapid simultaneous measurement of DNA, protein and cell volume in single cells from large mammalian cell populations. - Journal of Cell Biology 59: 766-771.

Debeaujon, I. \& Branchard, M. (1992): Induction of somatic embryogenesis and callogenesis from cotyledons and leaf protoplasts-derived colonies of melon (Cucumis melo L.). - Plant Cell Reports 12: 37-40.

De Vita, R., Cavallo, D., Eleuteri, P. \& Dellomo, G. (1994): Evaluation of interspecific DNA content variation and sex identification in falconiformes and strigiformes by flow cytometric analysis. Cytometry 16: 346-350.

Doležel J. \& Bartoš J. (2005): Plant DNA Flow Cytometry and Estimation of Nuclear Genome Size. - Annals of Botany 95: 99-110.

Doležel, J., Binarová, P. \& Lucretti, S. (1989): Analysis of nuclear DNA content in plant cells by flow cytometry. - Biologia Plantarum 31: 113-120.

Doležel, J., Greilhuber, J., Lucretti, S., Meister, A., Lysák, M.A., Nardi, L. \& Obermayer, R.
(1998): Plant genome size estimation by flow cytometry: inter-laboratory comparison. Annals of Botany 82 (Supplement A): 17-26.

Doležel, J., Greilhuber, J. \& SudA, J. (2007): Flow cytometry with plants: an overview. - In: Doležel, J., Greilhuber, J. \& SudA, J. (eds): Flow cytometry with plant cells. - pp. 41-65, Wiley-VCH Verlag Gmbh \& Co. KGaA, Weinheim.

Doležel, J., Sgorbati, S. \& Lucretti, S. (1992): Comparison of three DNA fluorochromes for flow cytometric estimation of nuclear DNA content in plants. - Physiologia Plantarum 85: 625-631.

Eder, M., Tenhaken, R., Driouich, A. \& Lütz-MeindL, U. (2008): Occurence and characterization of arabinogalactan-like proteins and hemicelluloses in Micrasterias (Streptophyta). - Journal of Phycology 44: 1221-1234.

Gajdová, J., Navratilová, B., Smolna, J. \& Lebeda, A. (2007): Effect of genotype, source tissue and media composition on Cucumis and Cucurbita protoplast isolation and regeneration. - Acta Horticulturae 731: 89-94.

Galbraith, D.W., Harkins, K.R., Maddox, J.M., Ayres, N.M., Sharma, D.P. \& Firoozabady, E. (1983): Rapid flow cytometric analysis of the cell cycle in intact plant tissues. - Science 220: 1049-1051.

Graham, J.E.; Wilcox, L.W., Graham, L.E. (2008): Algae (2nd Edition). - 720 pp., Benjamin Cummings, San Francisco, CA.

Gregory, T.R. (2001): Coincidence, coevolution, or causation? DNA content, cell size, and the C-value enigma. - Biological reviews 76: 65101.

Greilhuber, J., Doležel, J., LysÁK, M.A. \& Bennett, M.D. (2005): The origin, evolution and proposed stabilization of the terms 'Genome Size' and 'C-Value' to describe nuclear DNA contents. Annals of Botany 95: 255-260.

Guillard, R.R.L. \& Lorenzen, C.J. (1972): Yellowgreen algae with chlorophyllide C. - Journal of Phycology 8: 10-14.

HaIG, D. (2010): What do we know about Charophyte (Streptophyta) life cycles? - Journal of Phycology 46: 860-867.

HamadA, J. (1987): Diploidy in DNA content in vegetative cells of Closterium ehrenbergii (Chlorophyta). - Journal of Phycology 23: 541-546.

Hardie, D.C., Gregory, T.R. \& Herbert, P.D.N. (2002): From pixels to picograms: A beginners“ guide to genome quantification by Feulgen image analysis densitometry. - The Journal of Histochemistry \& Cytochemistry 50: 735-749.

Hoshaw, R.W., Wang, J.-C., McCourt, R.M. \& Hull, H. M. (1985): Ploidal changes in clonal cultures 
of Spirogyra communis and implications for species definition. American Journal of Botany 72:1005-11.

Iversen, O.E. \& LAerum, O.D. (1987): Trout and salmon erythrocytes and human leukocytes as internal standards for ploidy control in flow cytometry. - Cytometry 8: 190-196.

Inoue, A., Mashino, C., Kodama, T. \& OJima, T. (2010): Protoplast preparatoin from Laminaria japonica with recombinant alginate lyase and cellulase. Marine Biotechnology 13: 256-263.

Johnston, J.S., Bennett, M.D., Rayburn, A.L., Galbraith, D.V. \& Price, H.J. (1999): Reference standards for determination od DNA content of plant nuclei. - American Journal of Botany 86: 609-613.

KAPRAUN, D.F. (2005): Nuclear DNA content estimates in multicellular green, red and brown algae: Phylogenetic considerations. - Annals of Botany 95: 7-44.

KAPRAUN, D.F. (2007): Nuclear DNA content estimates in green algal lineages: Chlorophyta and Streptophyta. - Annals of Botany 99: 677-701.

KASPRIK, W. (1973): Beiträge zur Karyologie der Desmidiaceen.Gattung Micrasterias AG. Beih. Nova Hedwigia 42: 115-137.

Le Gall, Y.,Brown, S., Marie, D., MejJad, M. \& KloAREG, B. (1993): Quantification of nuclear DNA and G-C content in marine macroalgae by flow cytometry of isolated nuclei. - Protoplasma 173: 123-132.

Leitch, I.J. \& Bennett, M.D. (2007): Genome size and its uses: the impact of flow cytometry. - In: Doležel, J., Greilhuber, J. \& Suda, J. (eds): Flow Cytometry with Plant Cells: Analysis of Genes, Chromosomes and Genomes. - pp. 153176, Wiley-VCH, Weinheim, Germany.

LysÁk, M.A. \& Doležel, J. (1998): Estimation of nuclear DNA content in Sesleria (Poaceae). Caryologia 52: 123-132.

Lysák, M.A., Rostková, A., Dixon, J.M., Rossi, G. \& DoležEl, J. (2000): Limited genome size variation in Sesleria albicans. - Annals of Botany 86: 399-403.

Mann, D.G. \& PoulíčKovÁ, A. (2010): Mating system, auxosporulation, species taxonomy and evidence for homoploid evolution in Amphora (Bacillariophyta). - Phycologia 49: 183-201.

McLachlan, J. (1964): Some considerations of the growth of marine algae in artificial media. Canadian Journal of Microbiology 10: 769782.

Mefford, H., van den Engh, G., Friedman, C. \& Trask, B.J. (1997): Analysis of variation in chromosome size among diverse human populations by bivariate flow karyotyping. Human Genetics 100: 138-144.

Millner, P.A., Callow, M.E. \& Evans, L. V. (1979):
Preparation of protoplasts from the green alga Enteromorpha intestinalis (L.) Link. - Planta 147: 174-177.

Ondřej, V., Kitner, M., Doležalová, I., NÁdvorník, P., Navrátilová, B. \& Lebeda, A. (2009): Chromatin structural rearrangement during dedifferentiation of protoplasts of Cucumis sativus L. - Molecules and Cells 27: 443-447.

Preston, R.D. (1974): The physical biology of plant cell walls. - 491 pp., Chapman \& Hall, London.

Price, H.J. \& Johnston, J.S. (1996): Analysis of plant DNA content by Fuelgen microspectrophotometry and flow cytometry. - In: JAUHuR, P. (ed.): Methods of Genome Analysis in Plants: Their merits and Pitfalls. Chpt. 7. pp. 115-132, CRC Press Inc., Boca Raton, FL.

PoulíčKovÁ, A. \& Mann, D.G. (2006): Sexual reproduction in Navicula cryptocephala (Bacillariophyceae). - Journal of Phycology 42: 872-886.

Reddy, C.R.K., Dipakkore, S., Kumar, G.R., Jha, B., Cheney, D.P. \& Fujita, Y. (2006): An improved enzyme preparation for rapid mass production of protoplasts as seed stock for aquaculture of macrophytic marine green algae. - Aquaculture 260: 290-297.

Santisteban, M.S., Montmasson, M.P., Giroud, F., Ronot, X. \& Brugal, G (1992): Fluorescence image cytometry of nuclear DNA content versus chromatin pattern: a comparative study of ten fluorochromes - J. Histochem. Cytochem. 40: 1789-97.

Simon, N., Barlow, R.G., Marie, D., Partensky, F. \& VAULOT, D. (1994): Characterization of oceanic photosynthetic picoeucaryotes by flow cytometry. - Journal of Phycology 30: 922935.

Stace, C.A. (1991): Plant taxonomy and biosystematics (2nd Edition). - 272 pp., University Press, Cambridge.

Šmarda, P., Bureš, P., Horová, L., Foggi, B. \& Rossi, G. (2008): Genome Size and GC Content Evolution of Festuca: Ancestral Expansion and Subsequent Reduction. - Annals of Botany 101: 421-433.

TAkebe, I. \& Otsuki, Y. (1969): Infection of tobacco mesophyll protoplasts by tobacco mosaic virus. - Proceedings of the National Academy of Sciences USA 64: 843-848.

Tiersch, T.R., Chandler, R.W., Wachtel, S.S. \& Elias, S. (1989): Reference standards for flow cytometry and application in comparative studies of nuclear DNA content. - Cytometry 10: 706-710.

UpPalapati, S.R. \& FuJitA, Y. (2002): A simple method for mass isolation of protoplasts from species of Monostroma, Enteromorpha and Ulva (Chlorophyta, Ulvales). - Journal of Applied 
Phycology 14: 165-168.

Veldhuis, M.J., Cucci, T.L., Sieracki, M.E. (1997): Cellular DNA content of marine phytoplankton using two new fluorochromes: taxonomic and ecological implications. - Journal of Phycology 33: 527-541.

Wakabayashi, T., Kuboi, T., Tuboi, T., Kaji, M. \& Hara, M. (1999): Preparation of high yields of algal protoplasts using buccal juice of sea hare and commercial cellulase. - Marine Biotechnology 1: $407-410$
Wang, J.C., Hoshaw, R.W. \& McCourt, R.M. (1986): A polyploid species complex of Spirogyra communis (Chlorophyta) occuring in nature. Journal of Phycology 22: 102-107.

(C) Czech Phycological Society (2011)

Received December 17, 2010

Accepted May 1, 2011 